\title{
Analysis of Road Traffic Safety in Minna Niger State, Nigeria
}

Adebayo Owolabi OYETUBO ${ }^{1}$, Oluwa seyi J oseph AFO LABI ${ }^{2}$ and Muhammed Etudaiye OHIDA $^{3}$

${ }^{1}$ Olabisi Onabanjo University/Department of Transport Management, Ago-Iwoye , Nigeria 2Bells University of Tec hnology/Department of Mana gement Technology, Ota, Nigeria

3 Federal University of Tec hnology/Department of Transport Management Technology, Minna, Nigeria

\begin{abstract}
Road traffic accident is one of the major causes of death in Nigenia. Road accidents have taken away so many lives in Nigenia today that hardly does any single disease match its mortality prowess. People have died prematurely and properties worth several millions of Naira have been lost as a result of road traffic accident This papergives a full disc ussion on road traffic safety issues and the methodology used were through the collection of data using questionnaire and accident information from the Nigenia Police Force, PSC etc. The primary information for this research was sourced through the use of structured questionnaire, personal observation and interviews of road users in the study area. Secondary data emanated from published and unpublished sources such as govemment records, intemet, joumals, books etc. The findings were presented in descriptive and inferential form using frequencies, percentages, tables, mean and chi-square analytical techniques. The findings from the study revealed among many others; thatMale involved more in road accident compare to female counterpart in Minna Niger State. Pivate car had more accident compare to Taxi, The number of accident in each zone does not depend on the population of that zone, etc.
\end{abstract}

Key words - Accident, Traffic, Fatalities, Safety, Vehicle.

\section{INTRODUCTION}

In Nigeria, road transport is the dominant mode of movement for both freight and passenger traffic. The consequential effect of the negative extemalities of transport is accident with its attendant injuries and fatalities capable of neutralizing its social and economic benefits if not well managed. Traffic fatalities from a utomobile crashes have been known to be high in developing countries in which Nigeria constitute an integral part despite the much lower vehicle ownership in relation to population strength.

The increasing magnitude of fatal road traffic accident globally has been attributed to population explosion and increased level of motorization.

Road traffic accident has intensified to severe health, social and economic perils in developing countries. Road traffic accident cost $\$ 18$ billion throughout the world in low and middle income countries [3].

"[4]" road accident is one of the major public health issues in Nigeria. "[4]" opines that road traffic accident kills millions of people in Afric an countries.

Road traffic safety varies from one country of the world to another. Recent researches have shown that developing countries have more serious road accident problems than those of developed countries. "[9]" India is a developing country with worst road sa fety records, the govemment of India report over 118,000 road accident fata lities in 2008 , which ac counts for $9 \%$ of 1.2 millions fa ta lities of death in developing countries.

Most times govemment spend more money in campaigning and program were also designed to reduce driver's behaviour to dangerous driving such as over speeding and dangerous overtaking. 
All of these campaigns are not only done in the media, in fact along the road side, sign boards are placed wa ming drivers to a void dangerous driving. All this effort and campaign is to reduce crashes rate since safety is the ma in goal of transport.

Road accident is a mind boggling marvel. Aside from the humanistic part of road safety, the injury and fata lities of road accident has a genuine social and monetary outcome which have made an imminent explorer to be frightened of moving from one place to another. The effects of Road Traffic Accidents cannot be over-emphasized. Nigenia has a bad record of road traffic accident. Nigenia and Nigerians have had a fair share of losses in social and economic tems from road traffic accidents. People have died prematurely and properties worth several millions of Naira have been lost as a result of road traffic accident. While, losses a rising from suffering, bereavement and social disnuptions, which may be difficult to measure in monetary terms, are regarded as part of the basic social cost of accident. Social cost in terms of tra uma i.e. loss of closed relatives, associates, friends, father, mother etc. whic h eventually may lead to psychological depression. Other vic tims that might not have died may camy relics of handic a ps such as loss of limbs, blindness, or even bound to wheelcha ir for life. Such vic tims and families suffer severe psychologic al tra uma, often from stigmatization or mental imbalances.

Road Accidents have enthusiastic, physic al, social and monetary implic ations. The worldwide road auto collisions have been assessed to be $\$ 518$ billion every year with $\$ 100$ billion of that happening in developing nations [15]. Nigeria loses about 80 billion naira yearly to road accident. In a low wage nation, road traffic injuries assessed to be $1 \%$ of the gross national product (GNP). In middle income nation it is assessed to be $1.5 \%$ of the (GNP) and $2 \%$ in high income nation and both the low and center pay nation represent $\$ 65$ billion, more than they get in creating help [13].

Consequences of Road traffic accidents range from the physical, social, and economic impact it has on man to the economic impacts it has on the national economy and the impact it has on the vehic le itself. Road transport has had a modest contribution to the Gross Domestic Product of the economy over the years [2].

In spite of the centrality of damage as a general safety issue, few studies have been made conceming social and monetary effect of Road Accident. This is because of numerousvaria blesand the majority of which are identified with accessibility of related information [5].

"[1, 12]" reported that gross underestimation of Road a uto collisions injuries a nd fatalities in Nigeria could be because of an absence of adequate information gathering by govemment agencies. The financial expense of road traffic crashes and injury in Nigeria are huge. Road Traffic crashes and injuries have essentially countered Nigeria's financial desires and improvement because of the untimely loss of qualified and potential c ontributing experts and capable - bodied men and women in the work force.

In Nigeria, Road Traffic crashes have been one of the ma in causes of death connected with youthful and monetarily dynamic grown-ups between the ages of 30 to 49 years [10]. As a consequence of this, each road agencies in the nation are entrusted with proffering answer to Road auto collision that is tending to transportation Safety, each of these organizations find ways to deal with the diffic ulties of Road Traffic risk from altemate points of view. For illustrations, transport a uthorities are entrusted with distinguishing approaches to enhance the security of the general transport framework. 
In addition, they are responsible in retuming the system to the adequate operations following an accident. By comparison, the FRSC and the Nigeria police force focuses on enforcing laws and regulations to ensure that road users a re not put to danger by reckless driving of the other road users. Lastly, the officials also focus on how to prevent or how to care for the injured when road crashes occur i.e post crash situation.

"[6]" based on data that are best conservatives figures, Nigeria is a country with serious and growing accident issue and has one of the worst records in the world. He took the trend for 15years (19711985) and said that all the measures taken to solve road trauma is ineffective.

" $[8,11]$ " opines that the most important measures initiated by the govemment to handle Road Traffic Safety issues in Nigeria is the proclamation of Motor Traffic Regulation of 1913 which was limited to Southem part of Nigeria. In 1940 and 1945 the National Motor Traffic Regulation was reviewed in line with English Road Traffic Act of 1930. This is followed with the establishment of Road Traffic Police in 1960 with its roles and restriction clearly stated. In 1972 the Nigeria Amy introduced her one week yearly safety crusade to sensitise the populace on the perils of Road Traffic Accidents. A Highway Code was introduced in 1972 to guide road users on the uses of the road.

Following the Road Safety Management issues in the country and in an effort to face this unea siness, the Federal Road Safety Commission was established in 1988 by the Military Govemment to serve as a lead on Road Traffic Sa fety issues in Nigeria.

This paper providesan insight to the magnitude of spatial attributes of accident in Minna Niger State Nigeria with reference to geographical boundaries with respect to the local govemment. It catalogued the policy advocated by the govemment to reduce the magnitude of accidents. Road traffic accidents data were considered for the entire local govemment in Minna NigerState between 2006 and 2015. The data were analysed to establish the magnitude and variation in the pattem of occurrence of accidentsamong the local govemment in Minna Niger State. The data were analysed and presented with graphics of the pattem of accident fatalities among the local govemment to show at a glance the attributes of each of the local govemment within the period under investigation.

The a im of this research is to investigate into the possible causes of road traffic accidents in Minna Niger State Nigeria with the set objective of recommending general preventive mea sures. 


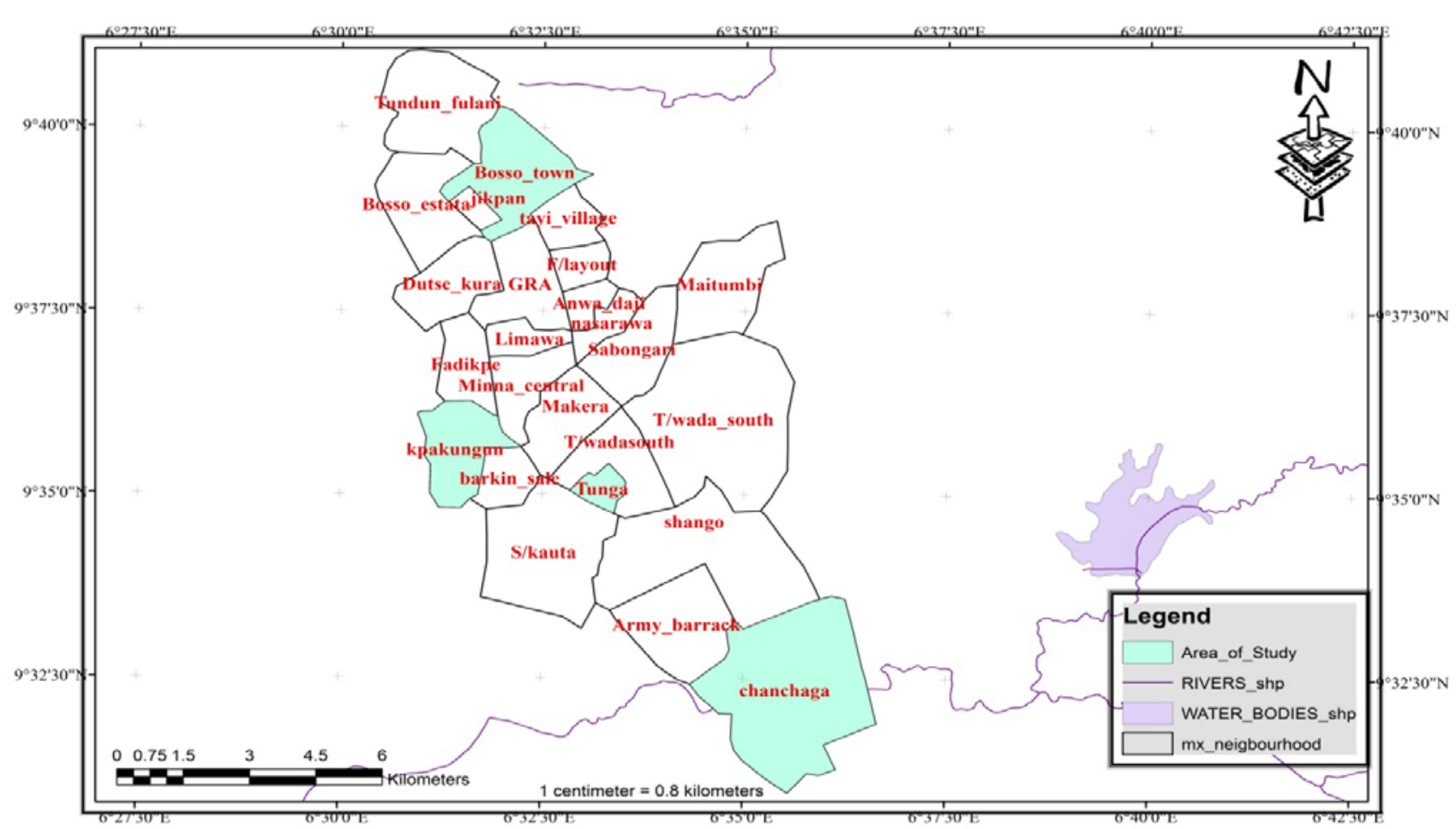

Fig.1: Niger State Map, showing the study area.

(Source: Department of urban and regional planning FUTMinna)

A. THE SAFE SYSTEM APPROACH

\section{THE METHODS}

Sa fe System Approach is based on the rules that ourneeds to tra vel should not be compromised with our life and health. It does not accept any degree of injury or death on the roads. It is designed with human in the centre, considering human mistake and exposure and admitting that the most scrupulous will make error at some spot. Its a im is to ensure that human error should not cause road accident and if crashes takes place it should not cause or lead to the death or disablement of the road users.

The obligation of the system is taken on by the polic y maker, transport planners, engineers, vehicle manufacturers, fleet managers and enforc ement officials, etc. while every road users abide by the rules of Safe System. It is a Iso in line with road safety management with wider social, ec onomic, and environmental goal, by creating partnership relation where transport official work tightly with other groups. Safe System undertakes other issues related with road traffic such as congestion, noise, a ir pollution and lack of physic al exerc ise.

There are three component of Safe system Approach which is;

1. Safer roads and roadsides

2. Safer speeds

3. Safer vehic les 


\section{Logistic $s$ \& Susta ina ble Transp ort \\ Vol. 9, No. 1, February 2018, 23-38 \\ doi: 10.2478/jlst-2018-0003}

- Safer roads and roadsides: Transport System is created to allow a hit survivable through the combination of road design and ma intenance of roads and roadsides.

- Sa fer vehic les: vehic les a re created with sa fety equip ment; this includes a ir c ushion, sea tbelts, etc .

- Safer speeds: the speed limit detemines the safety of road users in road perils. By taking a total survey of the aggregated elements involved in road safety, this approach promote an improve apprehension of the interaction between the identify factors of the road system: road users, roads and roadsides, vehicles and travel speeds (see diagram below).

Despite the system allowing for human mistake if road users surpass the safe speeds, then this approach will not be as effective. Controlling road users speeding conduct is vital to the success of the Safe System Approach

\section{Safe System}

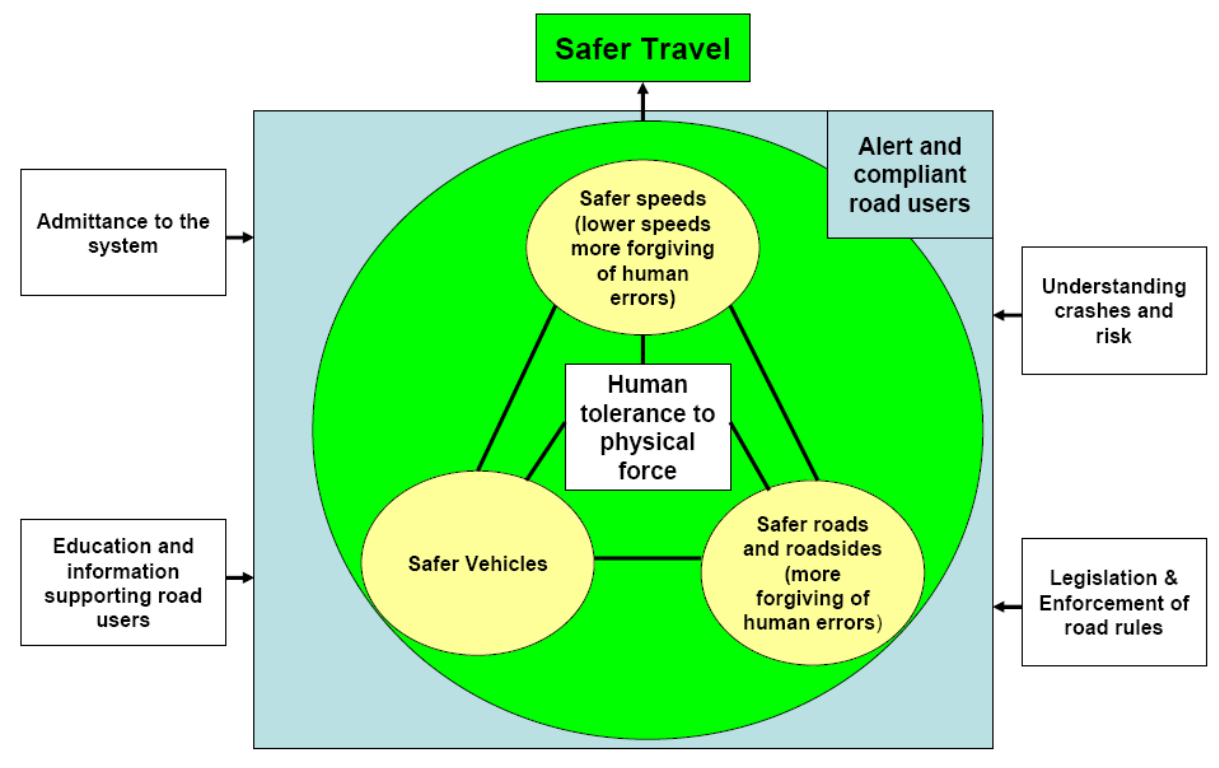

Fig. 2: Safe System Approach

Source - Australian Transport Council (2011)

B. Speed Factors in Safe System Approach

Achieving a Safe System of road travel is based on apprehension that the human body is vulnerable and unlikely to survive a sudden impact at a speed of more than $30 \mathrm{~km} / \mathrm{h}$. Even comparatively low speedscan kill or severely injure unless the vehicle, the road and roa dside environment ta ke account of the physic al vulnera bility of all road users.

The chance of surviving a crash reduces rapidly above certain impact speeds, depending on the nature of the collision. The diagram and table below show the approximated crash impact speeds based on the safest vehicles, where the forces are likely to surpass the permissiveness of the human body, i.e., those crashes that are probable to effect in death or severe injury. 


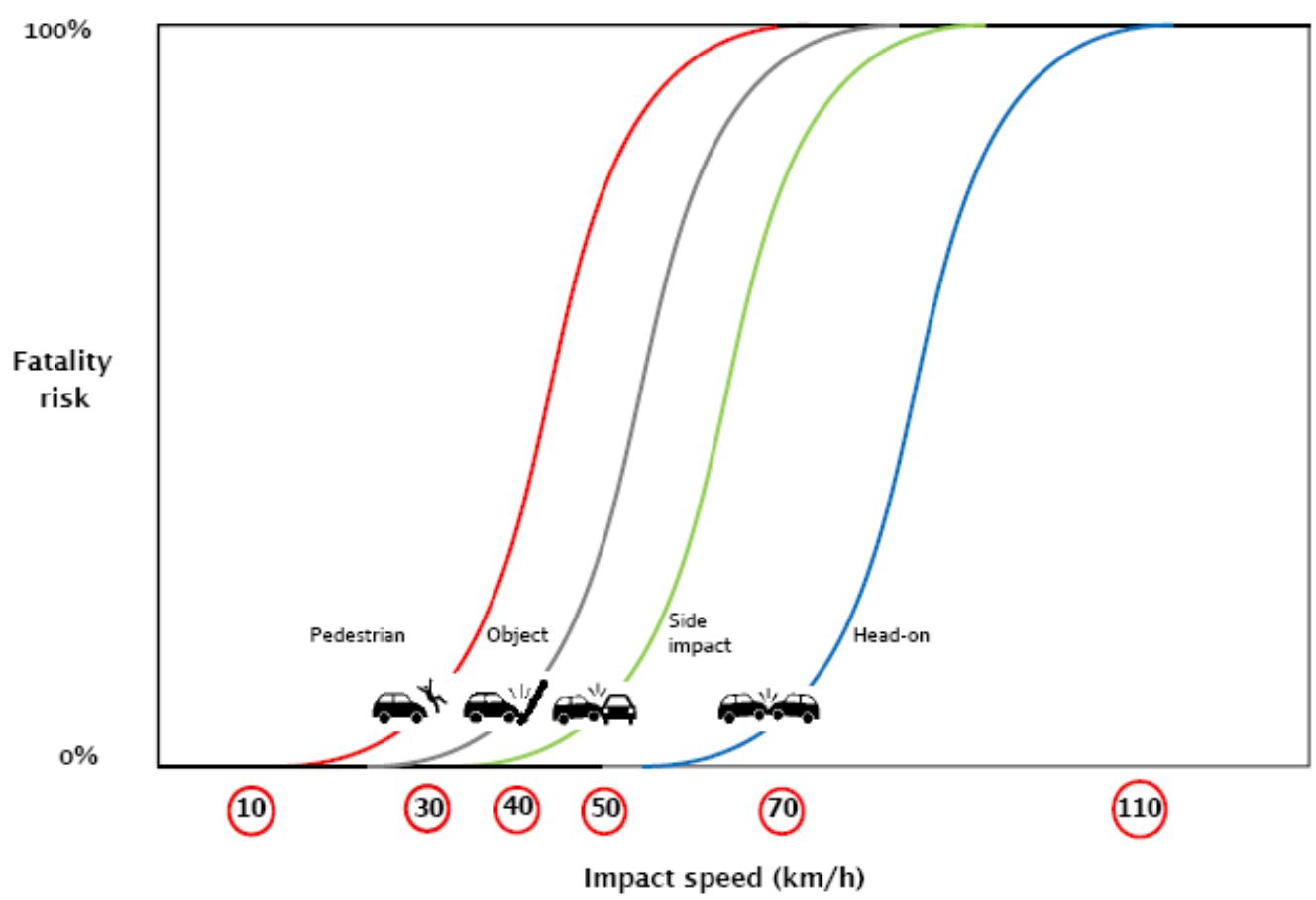

Fig. 3: graph of Fatality Risk/Impact Speed.

Source: Australian Transport Council (2011)

Table 2.1: Balance between Ha rm Reduction and Mobility in Setting Speed Limits.

\begin{tabular}{|l|c|l|}
\hline \multicolumn{3}{|c|}{ IMPACTSPEEDS ABOVE WHICH CHANCES OF SURVIVAL DECREASE RAPIDLY } \\
\hline Crash Type & $\begin{array}{l}\text { Impact } \\
\text { Speed }\end{array}$ & \\
\hline $\begin{array}{l}\text { Car/Pedestrian } \\
\text { or Cyc list }\end{array}$ & $\begin{array}{c}30 \\
\mathrm{~km} / \mathrm{h}\end{array}$ & Where there is a mix of vulnera ble road users a nd motor vehic le traffic. \\
\hline $\begin{array}{l}\text { Car/Pole or } \\
\text { Tree }\end{array}$ & $\begin{array}{c}40 \\
\mathrm{~km} / \mathrm{h}\end{array}$ & Where unprotected road ha za rds exist within defined clear zone. \\
\hline $\begin{array}{l}\text { Car/Car (Side } \\
\text { impact) }\end{array}$ & $\begin{array}{c}50 \\
\mathrm{~km} / \mathrm{h}\end{array}$ & $\begin{array}{l}\text { Where there is a likelihood of side impact crashes (eg, intersections or } \\
\text { access points). }\end{array}$ \\
\hline $\begin{array}{l}\text { Car/Car } \\
\text { (Head-on) }\end{array}$ & $\begin{array}{c}70 \\
\mathrm{~km} / \mathrm{h}\end{array}$ & Where there is no separation between opposing tra ffic streams \\
\hline
\end{tabular}

Source: Australian Transport Council (2011)

C. Sampling Techniques

This study relies mainly on the use of questionnaire survey and accident information from Nigeria police force Motor Traffic Division and the FRSC. A total of three hundred and eighty four questionnaires had been administered through hand delivery to the chosen respondents (road users), out of which 300 questionna ire were retrieved and a nalysed using SPSS. The value of the study and guidelines were disclosed to the respondents, this 384 questionnaires were amived at after determine the sample size. 


\section{Logistic $s$ \& Susta ina ble Transp ort \\ Vol. 9, No. 1, February 2018, 23-38 \\ doi: 10.2478/jlst-2018-0003}

The population of Minna in 2006 was 209,341 according 2006 census. Minna has a growth rate of $3.2 \%$. Data used in this study emanated from both primary and secondary sources. The primary information for this research was sourced through the use of structured questionnaire, personal observation and interviews on road users in the study area. Secondary data emanated from published and unpublished sources such as govemment records, intemet, joumals, books etc. The findings were presented in descriptive and inferential form using frequencies, percentages, tables, mean and chi-square a na lytic al tec hniques.

\section{RESULTAND DISCUSSION}

The specific socio-ec onomic characteristics of respondentsconsidered are gender, age and factors that cause an accident in Minna Niger State between 2006 and 2015. The elic ited responses are presented in the tablesbelow.

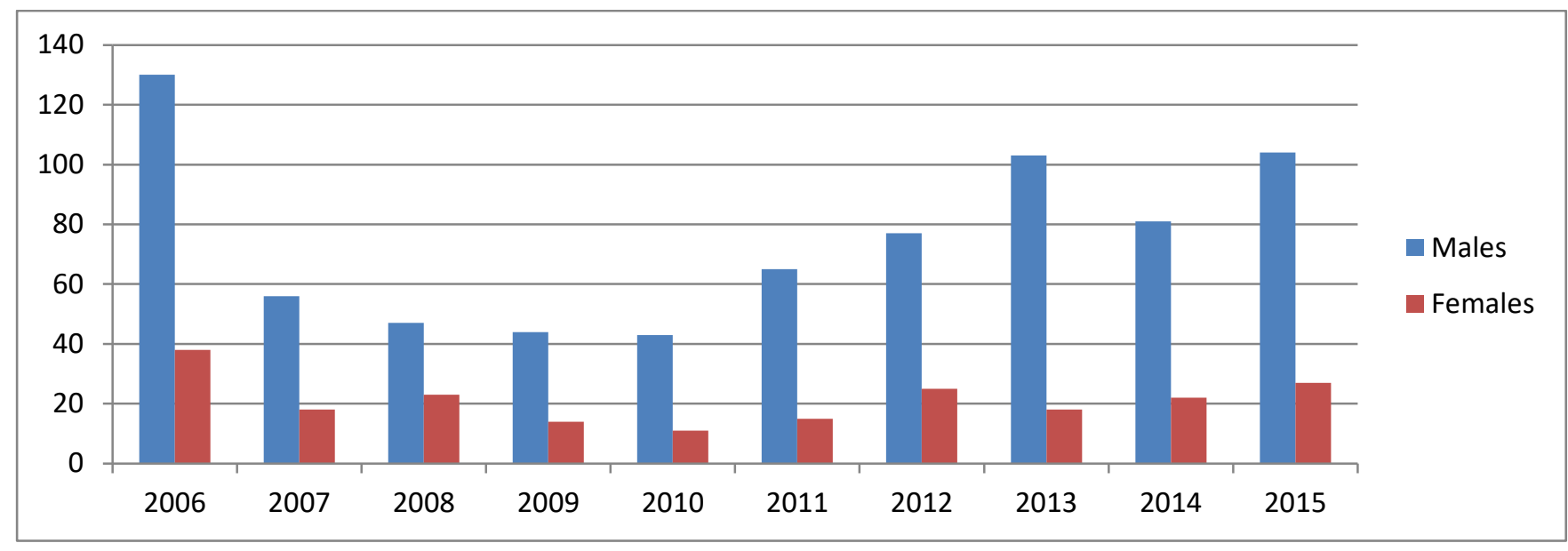

Fig.5.1: Aggregation of Accident Victim among Gender in Minna between 2006 and 2015 Source (a uthors survey 2016)

The graph above shows the aggregation of accident victims among genders between 2006 and 2015. The Y-axis represents the numbers of males and females who are involve in accident and the $\mathrm{X}$-axis represents the years in which the accident occurs. The graph indicates that there are more males who are involved in accident compare to females.

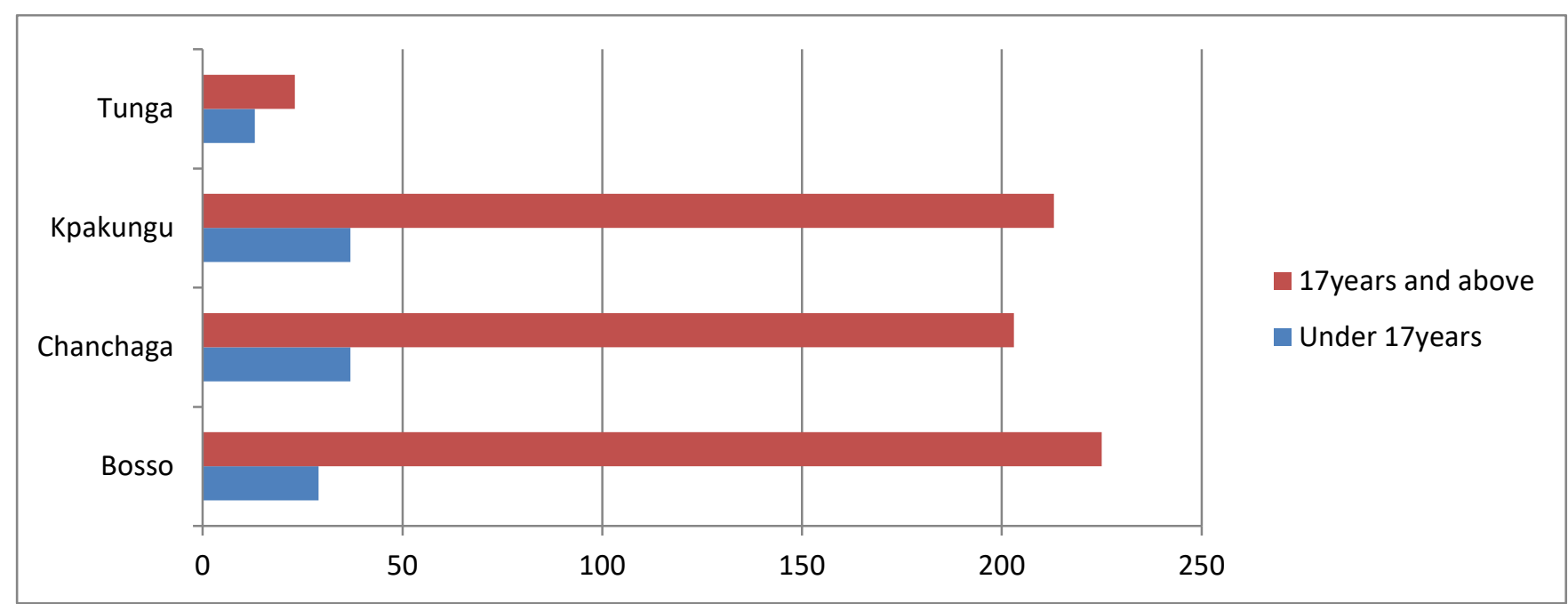

Fig.5.2: Showing the Age of Victims involves in Serious Accident

Source: a uthor's survey (2016) 


\section{Logistic $s$ \& Susta ina ble Transp ort \\ Vol. 9, No. 1, February 2018, 23-38 \\ doi: 10.2478/jlst-2018-0003}

From fig. 5.2 above, the $Y$-axis represents the va riouslocationsand the $X$-axis represent the age group of 17years above and under 17years. The graph indic ates that Bosso had high severe accident case among the age of 17years above, this is followed by Kpakungu, Chanchaga, and Tunga had low number of severe accident case among the two age groups. The graph also shows that both Chanchaga and Kpakungu had the same number of severe case among under 17years, this is followed by Bosso.

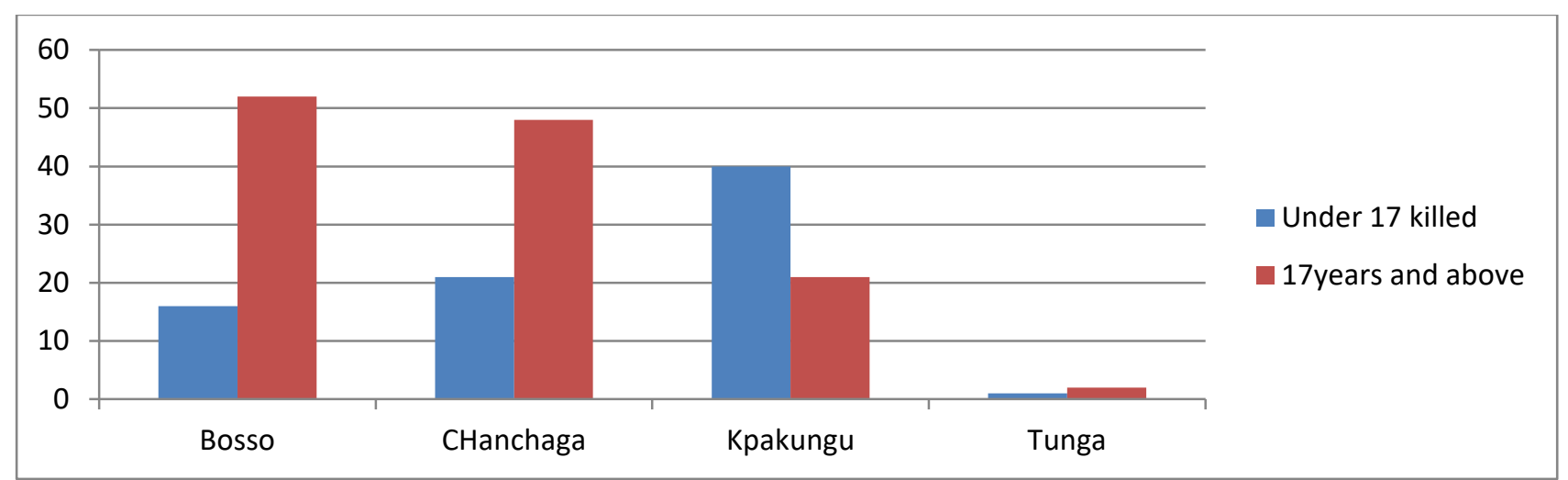

Fig. 5.3: Age of the Victims that was killed in Road Accident

Source: a uthor's survey (2016)

The graph above indic a testhat Bosso had high numbers of people among the age of 17yearsabove killed compare to Chanchaga, Tunga and Kpakungu. The bars also shows that under 17years killed are high in kpakungu, and this is followed by Chanchaga, Bosso and Tunga. There are low death records among the two age groups in Tunga.

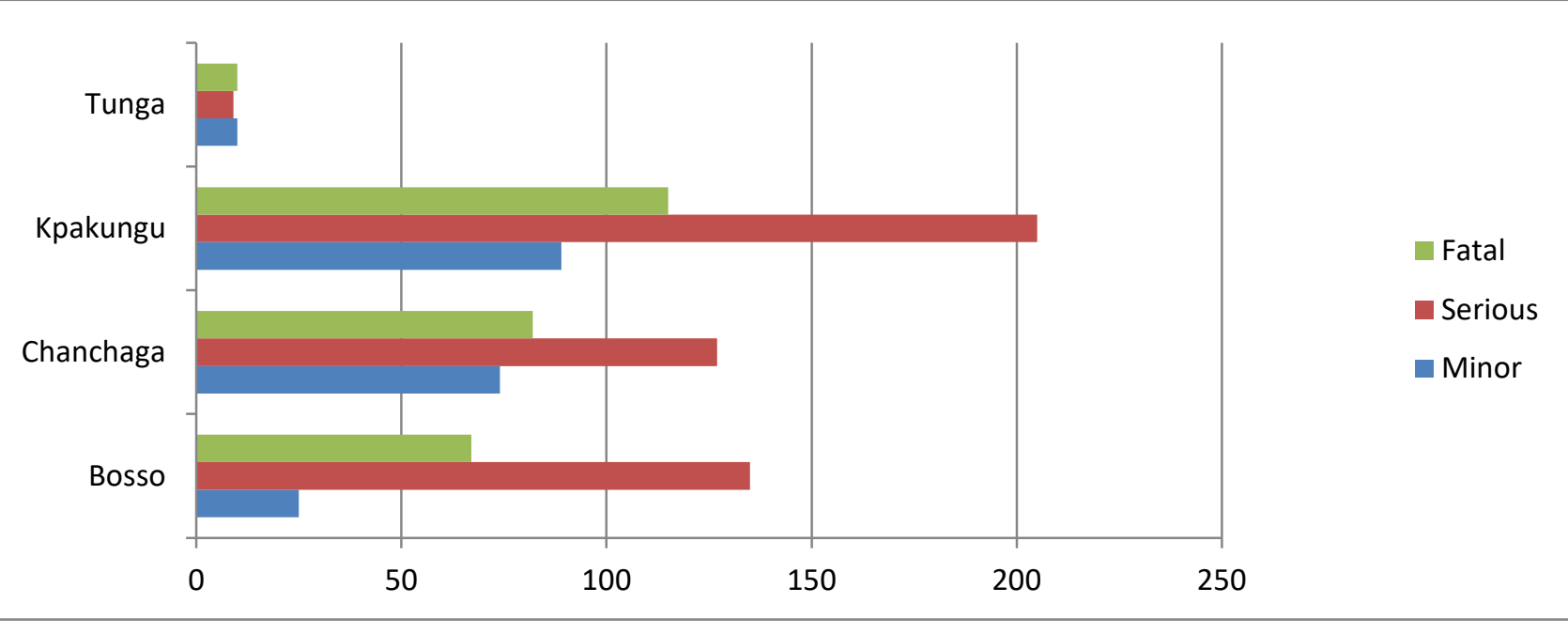

Fig.5.4 Showing Injury Cla ssific ation in Minna

Sourc e: a uthor's survey (2016)

fig.5.4 a bove showsa graph of injury c lassific ation in va rious location in Minna, the Y-axis of the graph represent the various location (I.e. Tunga, Bosso, Chanchaga, and Kpakungu) and the X-axis represents injury classification (i.e. Fatal, Minor, and serious injury). The figure above indic ates that Kpakungu had more serious injured victims resulting from road accident, follow by Bosso and Chanchaga. Also Kpakungu had more fatal accident followed by Chanchaga and Bosso. The graph shows that kpakunga had more Minor Injury followed by Chanchaga and Bosso, the rate of accident 
in Tunga is less. In summary, there are more fatal, serious, and minor accident in Kpakungu compare to the other three zones and Tunga had fewer accidents compare to the other areas.

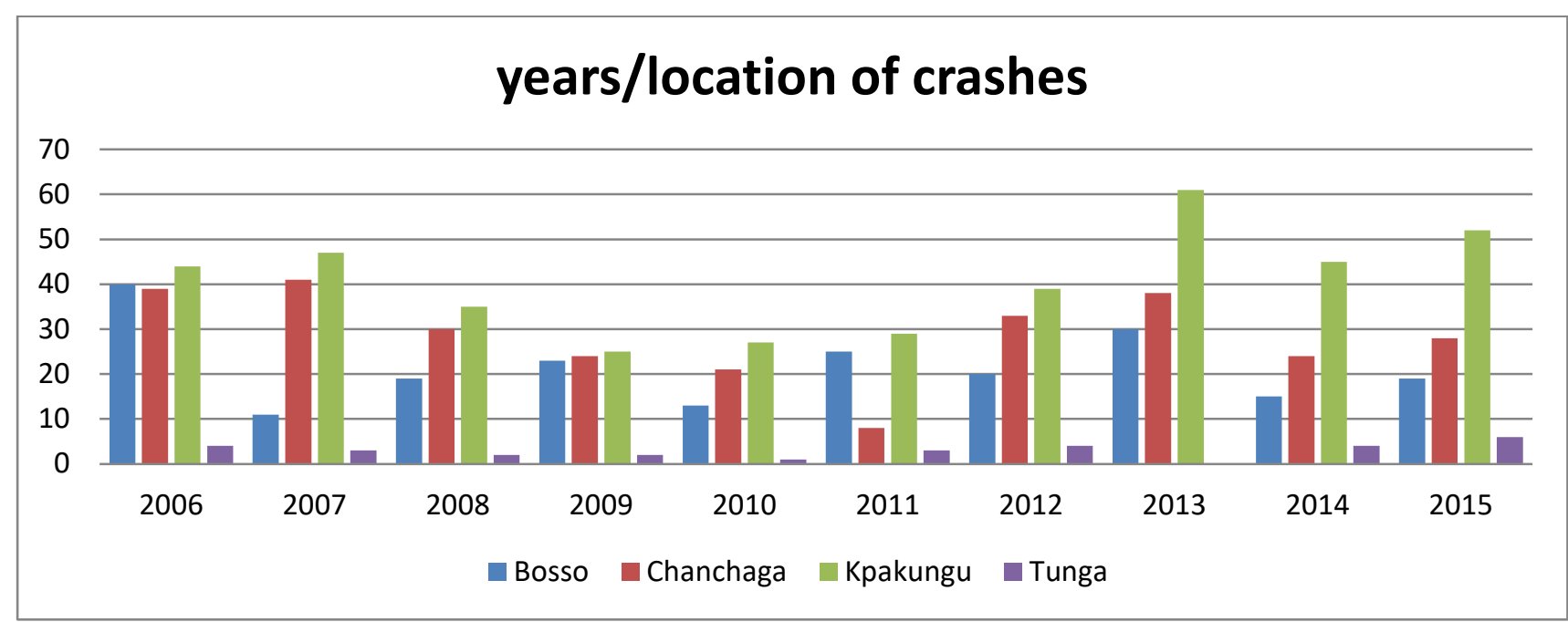

Fig.5.5: Showing Numbers of Accident ca ses between 2006 -2015

Sourc e: a uthor's survey (2016)

Fig. 5.5 above shows the graph of number of accidents between 2006 and 2015 at various loc ations in Minna. The $Y$-axis of the graph represents the number of accident cases while the $X$-axis of the graph represents the various loc ations in Minna in which the accident occurs from year 2006 to 2015.

The graph indic ates that the Rate of accident between 2006 and 2015 is not uniform, it is fluctuating among the various locations where in some location the accident rate might be high and in later years it may be low in other location. In summary kpakungu had high number of accident cases between 2006 and 2015, followed by Chanchaga, Bosso and Tunga.

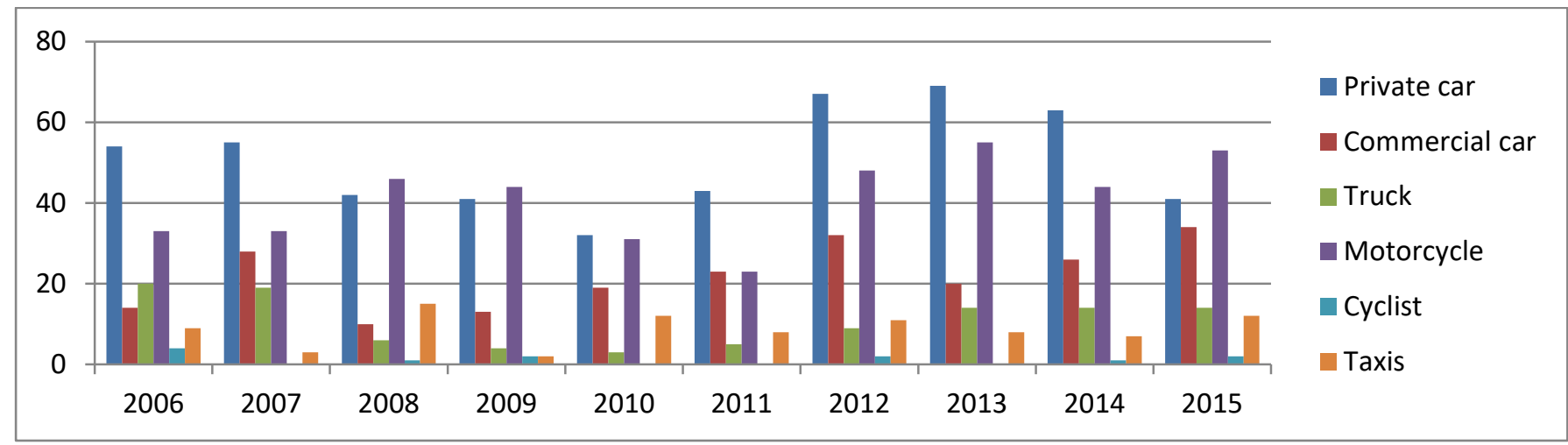

Fig.5.6: Types of Vehicles involve in Road Accident

Source: a uthor's survey (2016)

The graph above shows the varioustypes of vehic les that involve in accident in Minna between 2006 and 2015. It indicates that there is high rate of accident with private car and motorcycles followed by commercialcar and taxi, and there are fewer accident rates for cyclist. 
5.1 Causes of Road Traffic Accident in Minna.

Table 1: what do you think are the Major Cause of Road Accident in Minna

\begin{tabular}{|l|l|r|r|}
\hline \multicolumn{2}{|l|}{ Causes of Accident } & No of respondents & Percent \\
\hline Valid & poor road & 69 & 23.0 \\
& poor condition of vehic les & 21 & 7.0 \\
& reckless driving of motorist & 63 & 21.0 \\
& over speeding & 72 & 24.0 \\
& Impatience & 36 & 12.0 \\
& non compliance to general traffic rules & 39 & 13.0 \\
& Total & 300 & 100.0 \\
\hline
\end{tabular}

Source: author's field survey (2016)

From the Table 1 above the respondents are on the opinion that the above listed factorscause road traffic accident in Minna. The Table indic ate that about $23 \%$ of the respondents believes that poor road is the cause of road accident in Minna, $7 \%$ of the respondent said road accident is caused by the poor condition of the vehicle, $21 \%$ of the respondent said road accident are caused due to reckless driving of motorist, $24 \%$ of the respondent agrees that accident is caused due to over speeding, $12 \%$ of the respondent are on the opinion that road accident is cause due to impatience of the road users, while $13 \%$ of the respondents are on the opinion that accident is cause as a result of non compliance with general tra ffic rules.

Table 2: Distribution of the Respondents based on the use of Seatbelts

\begin{tabular}{|l|l|r|r|}
\hline \multicolumn{2}{|l|}{ Use of Seatbelts } & No of Respondents & Percent \\
\hline Valid & Ineffective & 60 & 20.0 \\
& & & \\
& Effective & 144 & 48.0 \\
& very effec tive & 96 & 32.0 \\
& Total & 300 & 100.0 \\
\hline
\end{tabular}

Sourc e: a uthor's field survey (2016)

Table 2 above indicate that $20 \%$ of the respondents a greed that the use of seatbelts is ineffective in reducing road crashes fatality, $48 \%$ of the respondents agreed that the use of seatbelts is effective in reducing road crashes fata lity and $32 \%$ of the respondent a grees that the use of seatbelts is very effective in reducing road crashes fatality. 
Table 3: Installation of Traffic Light in Selected Intersection

\begin{tabular}{|l|l|r|r|}
\hline \multicolumn{2}{|l|}{ Installa tion of traffic light } & No of Respondents & Percent \\
\hline Valid & Ineffective & 69 & 23.0 \\
& Effective & 171 & 57.0 \\
& very effective & 60 & 20.0 \\
& Total & 300 & 100.0 \\
\hline
\end{tabular}

Source: a uthor's field survey (2016)

Table 3 above shows that about 23\% of the respondents said installation of traffic light in selected intersection is ineffective in reducing road traffic accident, $57 \%$ of the respondent a re on the opinion that installation of traffic light in selected intersection is effec tive in curbing road traffic accident and $20 \%$ of the respondents a greed that installation of traffic light in selected intersection is very effective in curbing road traffic accident.

Table 4: Enforcement of Rules and Regulation

\begin{tabular}{|l|l|r|r|}
\hline \multicolumn{2}{|l|}{ Rules and Regulation } & No. of Respondents & Percent \\
\hline Valid & Ineffective & 84 & 28.0 \\
& Effective & 162 & 54.0 \\
& very effective & 54 & 18.0 \\
& Total & 300 & 100.0 \\
\hline
\end{tabular}

Source: a uthor's field survey (2016)

Table 4 Above shows that $28 \%$ of the respondents are on the op inion that enforc ement of traffic rules and regulation is ineffective in curbing road crashes in Minna, 54\% of the respondents said enforcement of traffic rules and regulation is effective in curbing road traffic crashes and $18 \%$ of the respondents are on the opinion that enforcement of traffic rules and regulation is very effective in curbing road traffic crashes in Minna.

Table 5: Maintenance of Road Networks 


\begin{tabular}{|l|l|r|r|}
\hline \multicolumn{2}{|c|}{ Maintenance of Roads } & No. of Respondents & Percent \\
\hline Valid & Ineffective & 141 & 47.0 \\
& Effective & 126 & 42.0 \\
& very effective & 33 & 11.0 \\
& Total & 300 & 100.0 \\
\hline
\end{tabular}

Source: a uthor's field survey (2016)

Table 5 above indic ates that $47 \%$ of the respondents are on the opinion that maintenance of road network is ineffective in curbing road traffic accident, $42 \%$ of the respondents agreed that maintenance of road networks are effective in curbing road crashes while $11 \%$ of the respondent said maintenance of road networks very effective in curbing road crashes.

Table 6: Public Enlightenment

\begin{tabular}{|l|l|r|r|}
\hline \multicolumn{2}{|c|}{ Public Enlightenment } & No. of Respondents & Percent \\
\hline Valid & Ineffective & 105 & 35.0 \\
& Effective & 159 & 53.0 \\
& very effective & 36 & 12.0 \\
& Total & 300 & 100.0 \\
\hline
\end{tabular}

Source: a uthor's field survey (2016)

Table 6 above indicates that 35\% of the respondents agreed that public enlightenment on safety rules is ineffective in curbing road traffic crashes, $53 \%$ of the respondents are on the opinion that public enlightenment on traffic safety rules is effective in curbing road traffic accident and $12 \%$ of the respondents said public enlightenment is very effective in c urbing road traffic crashes in Minna.

Table 7: Testing and certific ation

\begin{tabular}{|l|l|r|r|}
\hline \multicolumn{2}{|l|}{ Testing and certific ation } & No. of Respondents & Percent \\
\hline Valid & Ineffective & 135 & 45.0 \\
& Effec tive & 120 & 40.0 \\
& very effective & 45 & 15.0 \\
& Total & 300 & 100.0 \\
\hline
\end{tabular}

Source: author's field survey (2016)

Table 7 above indicates that $45 \%$ of the respondents said vehicle road worthiness testing and certific ation is ineffective in curbing road traffic accident, $40 \%$ of the respondents a re on the op inion that vehicle road worthiness testing and certific ation is effective in curbing road crashes and $15 \%$ of the respondents agreed that vehicle road worthiness testing and certification is very effective in curbing road crashes in Minna.

Table 8: Regulation and Issuance of Licence 


\begin{tabular}{|l|l|r|r|}
\hline \multicolumn{2}{|l|}{ Regulation and Issuance } & No. of Respondents & Percent \\
\hline Valid & Ineffective & 63 & 21.0 \\
& Effective & 177 & 59.0 \\
& very effective & 60 & 20.0 \\
& Total & 300 & 100.0 \\
\hline
\end{tabular}

Source: a uthor's field survey (2016)

Table 8 above shows that about 21\% of the respondents agreed that regulation and issuance of driving lic ence is ineffective in curbing road traffic crashes, $59 \%$ of the respondentsa re on the opinion that regulation and issuance of driving lic ence is very effective in curbing road crashes and $20 \%$ of the respondents sa id regulation an issuance of driving licence is very effective in curbing road traffic accidents.

\subsection{Tests for Hypothesis}

$\mathrm{H}_{\mathrm{o}}=$ there is no statistic al signific ant difference between accident caused by private vehic le to public vehic le by taxi

Deg. freedom $=(R-1)(C-1)$, where $D f=$ degree of freedom, $R=$ total number of row, and $C=$ total number of column. There fore

Deg. freedom $=(10-1)(2-1)=(9)(1)=9$

Deg. freedom $=9$ and Take significant level $(a)=0.05$

Table 9: Contingency Table

\begin{tabular}{|l|c|c|c|}
\hline Year & PRIVATE CAR & TAXI & TOTAL \\
\hline 2006 & $54(53.07)$ & $9(9.93)$ & 63 \\
\hline 2007 & $45(40.43)$ & $3(7.57)$ & 48 \\
\hline 2008 & $42(47.17)$ & $14(8.83)$ & 56 \\
\hline 2009 & $41(37.91)$ & $4(7.09)$ & 45 \\
\hline 2010 & $32(37.06)$ & $12(6.94)$ & 44 \\
\hline 2011 & $43(37.06)$ & $1(6.94)$ & 84 \\
\hline 2012 & $67(67.39)$ & $13(12.61)$ & 84 \\
\hline 2013 & $69(70.76)$ & $15(13.24)$ & 72 \\
\hline 2014 & $63(60.65)$ & $9(11.35)$ & 54 \\
\hline 2015 & $41(45.49)$ & $13(8.51)$ & 590 \\
\hline Grand Total & 497 & 93 & 80 \\
\hline
\end{tabular}

Source: Adapted from MTD (2016)

To get the expected accident valuesuse the following formulae; 
Logistic s \& Susta ina ble Transport

Vol. 9, No. 1, February 2018, 23-38

doi: $10.2478 /$ jlst-2018-0003

$E=\frac{R C}{T}$, where $R=$ row tota $I, C=$ column total, $T=$ grand tota $I$

$$
\begin{aligned}
& X^{2}=\sum \frac{(01-e 1)^{2}}{e 1} \\
& X^{2}=\frac{0.8649}{53.07}+\frac{20.8849}{40.43}+\frac{26.7289}{47.17}++++++++++++++++++\frac{20.1601}{8.51} \\
& X^{2}=0.0163+0.517+0.5667+0.2517+0.691+0.821+0.0023+0.0438+0.4432+0.0871+2.7489 \\
& \quad+3.0271+0.8717+3.6893+5.0841+0.0121+0.2339+0.4866+2.3689
\end{aligned}
$$

$$
X^{2}=22.064
$$

Ho =there is no statistical signific ant difference between male road accident vic tims to female Deg. Freedom $=(R-1)(C-1)$, where $D f=$ degree of freedom, $R=$ total number of row, and $C=$ total number of column. There fore

Deg. freedom $=(10-1)(2-1)=(9)(1)=9$

Deg. Freedom $=9$ and Take significant level $(a)=0.05$

Table 10: Contingency Table

\begin{tabular}{|l|c|c|c|}
\hline Year & Males & Females & Total \\
\hline 2006 & $130(131.11)$ & $38(36.89)$ & 168 \\
\hline 2007 & $56(57.75)$ & $18(16.25)$ & 74 \\
\hline 2008 & $47(54.63)$ & $23(15.37)$ & 70 \\
\hline 2009 & $44(45.27)$ & $14(12.74)$ & 58 \\
\hline 2010 & $43(42.14)$ & $11(11.86)$ & 54 \\
\hline 2011 & $65(62.44)$ & $15(17.57)$ & 80 \\
\hline 2012 & $77(79.61)$ & $25(22.39)$ & 102 \\
\hline 2013 & $103(94.43)$ & $18(22.62)$ & 121 \\
\hline 2014 & $81(80.39)$ & $22(26.57)$ & 103 \\
\hline 2015 & $104(102.24)$ & $27(28.76)$ & 131 \\
\hline Grand total & 750 & 211 & 961 \\
\hline
\end{tabular}

Source: Adapted from MTD (2016)

To get the expected accident valuesuse the following formulae;

$E=\frac{R C}{T}$, where $R=$ row tota $I, C=$ column total, $T=$ grand tota $I$

$$
\begin{aligned}
& X^{2}=\sum \frac{(01-e 1)^{2}}{e 1} \\
& X^{2}=\frac{(131-131.11)^{2}}{131.11}+\frac{(56-57.57)^{2}}{57.57}+\frac{(47-54.63)^{2}}{54.63}+\frac{(44-45.27)^{2}}{45.27}+++++++++++++++ \\
& \quad++\frac{(27-28.76)^{2}}{28.76}
\end{aligned}
$$

$X^{2}=0.00939+0.053+1.0656+0.0356+0.0175+0.1049+0.0856+0.7778+0.0046+0.0303+0.0334+$ $0.1885+3.7877+0.1246+0.0624+0.3759+0.3042$ 
$X^{2}=9.983$

\section{RESULTS OF CHI-SQUARE}

The researcher investigated the difference between accidents caused by private carand taxi, and the difference between male and female accident vic tim. The researcher takes the significant level of 0.05 , under the degree of freedom of value 9 it will give 16.92. According to the rules if the calculated value is greater than the Table value then we reject the null hypothesis and accept the altemative hypothesis. From the Table 9, the calculated value is 22.064 which are greater than the Table value (16.92) therefore we reject the null hypothesisand accept the altema tive hypothesis that states that there is sta tistic al signific a nt difference between accidents caused by private car to Taxi. And aga in from Table 10 the table value remains 16.92 and the calculated value is 9.983 , this clearly shows that the calculated value is not greater than the Table value therefore we accept the null hypothesis which states that there is no statistical significant difference between male and female involving in road accident..

\section{CONCLUSION AND RECOMMENDATION}

Road transport hascaused a lot of damage to lives and properties all over the world, being the most dominant means of transport in Nigeria it is highly concentrated and the threats to road sa fety have leads to adverse social and economic cost in the country. This paper has disc ussed the magnitude of accident fata lities and itspattem in Minna NigerState. The outc ome of data evaluation has shown particular variation in the pattem of road traffic accident and its attributes among the local govemment in Minna Niger State.

The study identify causes of accident in Minna, a nalysis of accident rate between 2006 and 2015, determine the existing safety measures put in place to curb accident and identify the challenges facing road safety management. This paperagreed with the causes of accident and ineffectiveness of Safety Measure used in Nigeria to Curb Road Accident in the work of [7].

Base on this problemsidentified, the following recommendations a re provided as follows;

i. Govemment of Niger state should make adequate funds available for regular and periodic maintenance of road network.

ii. There should be continuous monitoring of the Officers In charge of issua nce of driving license to prevent those road users who obta in their driving licence without undergoing driving test.

iii. Motorcycles should be ban for commercial senvice or restricted to the rural area and also those for private use should be heavily regulated through compulsory use of helmet.

iv. Govemment of Niger state should put other Transport stakeholders to work, by making it compulsory for those stakeholders to enlightening the public on Road Traffic Safety as part of their monthly or weekly program.

v. Accident black spot should be identified and Intelligent Transport System should be put in place in such area.

\section{REFERENCES}

1. Aderemo, A.J and Gladwell, M. (2015). Global positioning and Socio-Economic Impact of Road Traffic Accidents in Nigeria; matters a rising Americ an intemational joumal of contemporary research vol.5, No.5.

2. Agbonkhese, E. G. (2013). Road Traffic Accidents in Nigeria," Ca uses and Preventive Mea sures," Civil and Environmental Research J oumal.

3. Akinyemi, E.O. (2009). Contributing Road Transport Accidents on Rural Roads in Nigeria, Traffic Accidents in Developing Country, University press Lagos. 
4. Anothony Albanese, M.P. (2012). The effectiveness of FRSC public Education programme on drivers Road Traffic Habit in Lagos and Oyo state of Nigeria, British joumal of Arts and social science ISSN; 2046-9578, vol. 6 no 1.

5. Asalor, J . O. (2010). Towards Improved Road Safety in Nigeria. Technical Report No. Rts/00/82/011, Faculty of Engineering, University of Benin.

6. Asogwa, S.E. (1992). Road Traffic Accidents in Nigeria: a review on appraisal" Accident Analysis and Prevention. Vol. 24, No. 2, pp. 149-55.

7. Atubi, A.O. (2012) Determinants of Road Traffic Accident Occurrences in Lagos State: some Lessons for Nigeria. IntemationalJ oumal of Huma nities and Social Sc ience. Vol. 2, No. 6, Pp. 252-259.

8. Balogun (2014). Road Transportation and Traffic Law enforcement in Nigeria; a case study of Federal road safety coms (FRSC), West Afric an joumal of industrial and ac a demic resea rch vol. 11 no. 1.

9. Baluja, R. (2011). Examining Road Safety through the prism of Road traffic violations.

10. Murray, C.S. and Lopez, A. (1996). global positioning and Socio-Economic Impact of Road Traffic Accidents in Nigeria; matters Arising American intemational joumal of contemporary research vol.5, No.5.

11. Nwaegbe, K. (2008). Rescue and Management of Road Traffic Accident Victims in Nigeria: Challenges and Prospects, National Institute, Kuru.

12. pratte, D. (1998). Road to Ruin: Road Traffic Accident in the Developing World", NEXUS, Vol. 13, pp. $46-62$.

13. Sa fety - Net (2006). "European road sa fety observa tory a nnual sta tistical report" Work package 1 Task 3, Deliverable No. D1. 1.

14. Tutu, D. (2007). G8 must act to prevent road deaths in Africa retrieved from .http//www.makeroadssafe.org .

15. World Health Organization (2009), World Health Organization, Geneva.

\section{AUTHORS}

A. Adebayo Owolabi OYETUBO holds a Master of Science (M.Sc.) in Transport Studies from the Olabisi Onabanjo University, Ogun State Nigeria and currently a doctoral student in Transport Studies. (email: oyetuboadebayo@gmail.com).

B. Oluwaseyi Joseph AFOLABI is with the Bells University of Technology, Management Technology Department, College of Management Sciences, Ota, Ogun State, Nigeria. He is a lecturer in Logistics and Supply Chain Management and doctoral student with research interest in Transport safety and education, and Logistics and physical distribution management. (email: afolabiseyo@yahoo.com).

C. Muhammed Etudaiye OHIDA holds a Bachelor of Technology (B.Tech.) in Transport Mana gement Technology from the Federal University of Tec hnology, Minna, Nigeria and currently an M.Sc student in Transport Studies in Olabisi Onabanjo University, Ogun State Nigeria.

Manusc ript received by 25 September 2017. 